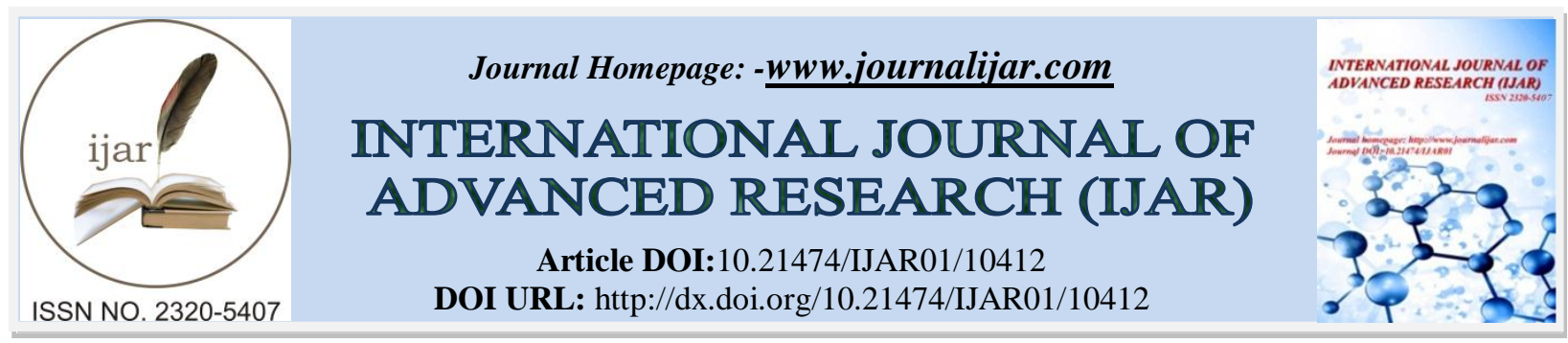

RESEARCH ARTICLE

\title{
PROGRAM EVALUATION OF HUMAN RESOURCE MANAGEMENT OF INDONESIAN NAVY SUPPLY OFFICER : CONTEXT PHASE
}

Diki Atriana, Billy Tunas and Tuty Sariwulan

\section{Manuscript Info}

\section{Manuscript History}

Received: 30 November 2019

Final Accepted: 31 December 2019

Published: January 2020

Key words:-

Program Evaluation, CIPP Model,

Indonesian Naval Supply Officer,

Human Resource Management

\section{Abstract}

The purpose of this research was to evaluate human resource management program of Indonesian Navy Supply officer corps. Indonesian Navy has eight branches of corps of to fulfill its tasks and goals. In 2001 Supply corps has been named formally replacing administration corps and since that time there was no formal evaluation has ever been made. This is a qualitative research using Context Input Process Product (CIPP) model but this paper research is only focus to context phase. Data are collected through observations, focus group discussions, dialogues,andsurvey questions. The result of this context thatit is stated on the Indonesian legislation law no 34 of 2004 article 9 about the task of Indonesian navy. In order to do the tasks Indonesian navy officers should have a proper competence in terms of duty, rank, education and psychology.Even though, the navy has not only a clear planning documents phase such as working planning frame works but also rules and regulation concerning how to manage human resource. But there is no such as a clear link between each other. After all, it is clear that the program is vital and significant for the navy and need to be refined in the near future.

Copy Right, IJAR, 2020,. All rights reserved.

\section{Introduction:-}

As stated on the Indonesian legislation law no 34 year 2004 article 9 about the task of Indonesian navy is required not only systematic rules and regulations but also capable personnel.Organization whether profit or non-profit is formed with a specific goal and is divided into units with a clear division of work, procedure and mechanism. This would be considered as organization performancethat will be an indicator achievement between processes with results to fulfill its tasks. The ultimate goal of the navy to fulfill its mission depend upon many things such as: human resource, methods, machines, organization development, operational capabilities. Thus, it is important to have a right, qualified, professional and modern human resource management approach that could be adopt and adapt with dynamic changing environments. One of the significant factorsand vital could create added value is human resource management. It not only treats as an asset of an organization but it also considers as a capital. One of the valuable efforts for an organization to develop its employee is to maintain its capacity, capability and professionalism. The Indonesian navy realize that capable personnel plays a vital role to fulfill its mission. In order to do that, the Indonesian navy has eight branches of division of work and well known as an officer corps; operation, electronics, technician, supply, marine, health, military police and law. Each corps has a specific task and function but with one main goal to achieve the navy goals and objectives. Others requirement concerning of the rank, physical fitness, psychological and education background. No wonder that it needs to be managed carefully. According to Thoha (2014), management is a process, result or a statement to be better, in order to change, move 
forward, enhance, develop, evaluate or any possible thing to happen. So, management is an important success factor to complete its mission.

Wibowo (2012), a superior will manage his staffs to produce an effective and efficient way to do the job done.It is important that a proper human resource management system with professionalism and modern way should be in first place to adapt the fast change of information and technology in this competitive era. Gary Dessler states that there are five function of management: planning, organizing, staffing, leadership and controlling (Dessler, 2013).

Historically, the supply corps has been existing since the navy plays as military role in Indonesian administration. Legally, the name of corps has changed since 2001. The previous what so called administration corps. Since that time there was no formal evaluation about how the effective management of supply corps ever done. Thus, evaluation plays an important factor to be able to exercise how far the organization did and how well did it?

\section{There are several critical components of this view of evaluation (Alkin, 2004):}

1. evaluation is social research applied to answering policy-oriented question.

2. The primary aim of evaluation is to aid stakeholder in their decision making on policies and program.

3. Evaluation involves making judgments.

Daniel L. Stufflebeam define that "Evaluation is the process of delineating, obtaining, reporting, and applying descriptive and judgmental information about some object's merit, worth, probity and significance in order to guide decision making, support accountability, disseminate affective practices, and increase understanding of the involved phenomena."(Stufflebeam, 2000).

Time has change so does the military strategy. The navy roles have developed not only using hardware power to destroy enemy but also using soft power and smart power.Due to the facts, that in the future the challenges and threats are facing by the Indonesian navy nationally, regionally or globally become more complex than before. The Indonesian navy, Supply corps in specific, considers that applying the best human resource management system is necessary. Furthermore, since the supply corps has been renamed in 2001, there was no single comprehensive evaluation been made. Some problems concerning human resource management in supply corps were arised such as no open communication between personnel and the management, no clear of division of work in one of supply specialization which are supply and clerical profession and no clear career paths.

Even though there are no universal characteristics of human resource management (HRM). Different organizations have different models and practices. Thus, often only corresponding to the conceptual version of HRM in a few respects. But due to task and responsibility of supply chief corps as stated in the formal rules and regulations not all the HRM activities covers by the supply HRM. This limitation in order to divide task proportionally through the HRM organization in the navy.

Based upon the background as mention earlier, the research question for context is how to analyze need assessment, policy and the purpose of the supply officer program in order to support the navy tasks?

\section{Methodology Research:-}

This research paper is a qualitative research applied Context Input Process Product (CIPP)evaluation model develops by Stuffebeam.Guili Zhang, et. al., "the CIPP evaluation program belongs in the improvement/accountability category and is one of the most widely applied evaluation models(Zhang, 2011).The main components of CIPP could be described as shown in figure below.

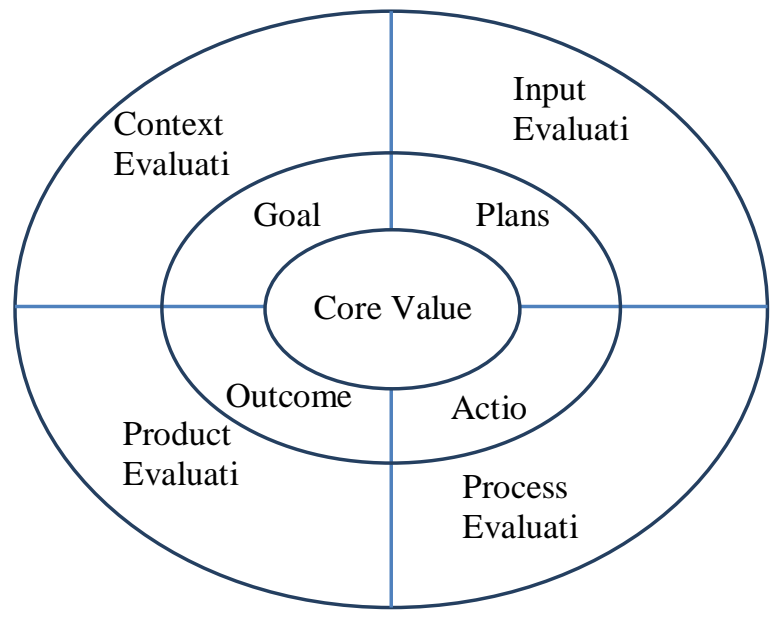


Source: Stufflebeam, L. Daniel dan Shinkfield, J. Anthony, Evaluation Theory, Models \& Applications (San Francisco: Josey-Bass, 2007. P 333)

Context evaluation provides information for the development of and evaluation of mission, vision, values, goals and objectives and priorities. The purposes are to define the characteristics of the environment, to determine general goals and specific objectives and to identify and diagnose the problems or barriers which might inhibit achieving the goals and objectives. The methods applied include conceptual analysis to define limits of population to be served, empirical studies to define unmet needs and unused opportunities, judgment of experts and clients on barriers and problems and judgment of experts and clients on desired goals and objectives. Input evaluation provides information for the development of program designs through evaluation of data bases, internal and external stakeholders' interests, weaknesses, opportunities, strengths and threats. The purposes are to design a program (intervention) to meet the objectives, to determine the resources needed to deliver the program and todetermine whether staff and available resources are adequate to implement the program. Process evaluation develops ongoing evaluation of the implementation of major strategies through various tactical programs to accept, refine, or correct the program design. The purpose is to provide decision makers with information necessary to determine if the program needs to be accepted, amended, or terminated.The methods applied as follow a staff member serves as the evaluator, then this person monitors and keeps data on setting conditions, program elements as they actually occurred. Finally, this person gives feedback on discrepancies and defects to the decision makers.Product evaluation provides evaluation of the outcome of the program to decide to accept, amend or terminate the program, using criteria directly related to the goals and objectives. The purpose is to decide to accept, amend, or terminate the program. The method used is traditional research methods, multiple measures of objectives, and other methods.

The collection information did in many ways such as: specify the source of the information to be collected, specify the instruments and methods for collecting the needed information, specify the sampling procedure to employed and specify the conditions and schedule for collecting the information.Data are collected directly according to goals of research using qualitative methods such as: observation, interviews, focus group discussions and survey to selected officers. Due to qualitative research characteristics, informan in this research set by purposive sampling (Lincoln and Guba, 1985).

\section{Result and Discussion:-}

Every management activity could be valued when all the process is under gone after evaluation. Human resource management is done in order to create quality and value personnel that could lift up or leverage the organization added value systematically. According to Harris (2010) that evaluation as the use of social research methods to systematically investigate the effectiveness of social intervention programs in ways that are adapted to their political and organizational environments and are designed to inform social action to inform social conditions. Alkin (2004) stated that there are several critical components of this view of evaluation: a) evaluation is a social research applied to answering policy-oriented question; b) the primary aim of evaluation is to aid stakeholders in their decision making on the policies and program; and c) evaluation involves making judgements.

Due to the scope and limitation of this paper research, all the discussion is about CIPP but the context only. The result of this research based upon the CIIP model can be explained as follow:Context evaluation provides information for the development of and evaluation of mission, vision, values, goals and objectives and priorities.First, it evaluated the need for evaluation of the program, the policy based behind and the goals of the program. The fact found that there is a strategic planning framework set which are a five year and yearly as Indonesian navy strategic planning. The supply corps chief also declares how to conduct human resource management of supply officer and documented in working program and budgeting. Not only it was clear that the mission, vision, value of the supply corps was set and documented, but also it was clearly stated and was reviewed yearly.Bratton and Gold (2007) stated that human resource management as a strategic approach concerning developing of human capability in order to achieve competitive advantageto integrated policy management, program and implementation. Amstrong (2010) also stated that human resource management is a strategic approach, integrative and coherent to develop and satisfy personnel who work for organization. Another aspect found in the field thatthe Indonesian navy core values, namely as Trisila TNI AL, consist of three elements: discipline, hierarchy and military honor. These values should be implying in their day-to-day life and defines as naval organization culture life. 
On the other hand, supply corps needs qualified officer to fulfill the mission and the job done. Qualification officer must be comply with: rank, education background, physical fitness and psychological standard test. In order to do that it must be an identification need assessment of standard competency such as tour of duty, education, rank and mentality and attitude. Those requirements are also documented in technical book of supply officer human resource management. Based on these standards, then, a program management was set. Simamora stated that the usefulness of program or coaching is to set attitude, loyalty and team work beneficial and meeting the need of human resource management planning (Simamora, 2011). According to Schuler, one of organization human resource strategy and development is necessity approach need assessment. Identification and refine gap of skill personnel and it is a reactive approach. From this point of view, it is clear that the need of supply officer with its standard competencies to do the job done has reached its goals. In line with this, Rivai comments that management program or coaching to personnel is a systematic process to change attitude to reach organization goals. The need is in line with requirement job position (Rivai and Sagala, 2009). The navy has done these quite well and it was documented in many forms of documentations.

Furthermore, the fact found that policy program was based upon the chief of naval staff strategic planning and policy order, policy and direction. Then, the supply chief corps forms a working budgeting planning program. The main goal of the program was to govern and manage human resource of supply officer using common knowledgeof modern human resource management method, in order to be able to do the job as required. The fact found that the strategic planning was set at headquarter level into four programs and one of them is professionalism program. But there is unclear link and match between chief of naval staff strategic planning and working budgeting program of supply chief corps. The corps supply did not have a valid information about any evaluation about this program.

The goal of supply officer management program is fundamentally to enhance and develop the basic capabilities of supply officer to able to do in the area of financial, supply and clerical. In order to achieve that one factor that should take into consideration is software. The main software used to govern the supply human resource management are the chief of naval staff rules no 1 and 2 of 2010 which regulate the profession and corps in the navy. Based on in this the supply chief corps produces supply officer human resource management manual book with its last edition was 2014. In 2016, the financial organization was changed and developed where forming a financial sector in every naval base and its additional task is to be of supply coordinator. Unfortunately, the naval base financial organization is not accommodated in the manual book.

\section{Conclusion:-}

Context evaluation provides information for the development of and evaluation of mission, vision, values, goals and objectives and priorities. In terms of policy matter, the program management is still valid based on criteria and the need of competence of supply officer to do the job done also has satisfied the criteria. It is also stated in the legislation law no 34 of 2004 article 9 about the Indonesian navy tasks. The navy also has a strategic planning framework in five year and yearly scheme. Following that regulation, the navy also has regulation software concerning the human resource management that are chief of navy regulation no 1 and no 2 of 2010.Moreover, the navy has a solid core values namely as Trisila, such as: discipline, hierarchy and military honor that has been imply as organizational culture.In chief of supply side there is a manual book of human resource management of 2014 but unfortunately it is not aligned with the development of financial institution which is in place in every naval base. Furthermore, as mention in manual book that the supply chief is formed underbow organization in order to manage and regulate the supply officer management in the area of responsibility by the financial institution. In general, the goal of the program was set and linked to naval strategic planning. Other than that, the supply management human resource program imitates the model of human resource management in common but with limited aspects.

\section{References:-}

1. Afrizal. (2014). Metode Penelitian Kualitatif. Jakarta: Raja Grafindo Persada.

2. Alkin, M. C. (2004). Evaluation Roots: Tracing Theoritists, Views and Influences. UK: Sage Publication Lts.

3. Alwi, S. (2001). Manajemen Sumber Daya Manusia, Strategi Keunggulan Kompetitif. Yogyakarta: Badan Peneribut Fakultas Ekonomi.

4. Amstrong, M. (2012). Amstrong Handbook's of Human Resourches Management. Hong Kong: Graphicraft Limited.

5. Arikunto, S. dan Safrudin, C. (2009). Evalausi Program Pendidikan: Pedoman Teoritis Praktis bagi Mahasiswa dan Praktisi Pendidikan, Edisis Kedua. Jakarta: Bumi Aksara. 
6. Arikunto, S. dan Safrudin, C. (2009). Praktis Bagi Mahasiswa dan Praktisi Pendidikan. Jakarta: Bumi Aksara.

7. Bogdan. R. C. dan Biklen, S. K. (1992). Qualitative Research for Education: An Introduction to Theory and Methods. Boston: Allyn and Bacon Inc.

8. Brinkerhoff, R. O. (1986). The Program Evaluation: a Practioner's Guide for Traineers and Educationer,Fourth Edition. Boston: Kluwer Nijboff Publishing.

9. Creswell, J. W. (1998). Research Design: Qualitative and Quantitative Approaches. New York: Sage Publications Inc.

10. Denzim, N. K. dan Lincoln, Y. S. (2000). Handbook of Qualitative Research, 2nd Edition. London: Sage Publications, Inc.

11. Dessler, G. (2013). Human Resources Management. US: Pearson.

12. Djaali, P. M. dan Ramiy. (2000). Pengukuran dalam Bidang Pendidikan. Jakarta: Universitas Negeri Jakarta.

13. Fitzpatrick, J. L., dkk. (1995). Program Evaluation Alternative Approaches and Practical Guidelines. New York: Pearson.

14. Gallwey, T. (2003). Coaching Guide. Welsh Government: Public Service Management Wales.

15. Gomes, F. C. (2003). Manajemen Sumber Daya Manusia. Yogyakarta: Andi.

16. Harris, M. J. (2010). Evaluating Public and Community Health Programs. San Fransisco: Jossey-Bass.

17. Hasan, M. (2008). Metode Penelitian. Bandung: Universitas Katolik Parahyangan.

18. Hasibuan, M. S. (2012). Manajemen Sumber Daya Manusia. Jakarta: Raja Grafindo Persada.

19. Huba, E. G. (1981). Effective Evaluation: Improving the Useulneess of Evaluation Results Through Responsive and Naturalistic. California: Jossey-Bass Inc.

20. Issac, S. dan Michael, W. B. (1982). Handbook in Research and Evaluation, 2nd Edition. California: Edits Publisher.

21. Jackson, J. H. dan Mathis, R. L. (2012). Human Resourches Management, 13th Edition. Boston: South-Western Cengage Learning.

22. Kaufman, R. dan Thomas, S. (1980). Evaluating without Fear. London: New Viewpoints.

23. Kussriyanto, B. (2007). Meningkatkan Produktivitas Karyawan. Jakarta: Pustaka Binaan.

24. (t.thn.). Lampiran Keputusan Pengab No. Kep/06/X/1991 Tanggal 5 Oktober 1991 tentang Petunjuk Pembinaan Prajurit ABRI.

25. (t.thn.). Lampiran Keputusan Pengab Nomor: Kep/06/X/1991 tentang Buku Petunjuk Dasar Pembinaan Prajurit ABRI.

26. Lincoln, Y. S. dan Guba, E. G. (1985). Effective Evaluation. San Francisco: Josey-Bass Publishers.

27. Mangkunegara, A. P. (2009). Manajemen SUmber Daya Manusia. Bandung: Remaja Rosdakarya.

28. McClelland, D. C. (2005). The Achieving Society. New Jersey: D. Van Nostrand Company Inc.

29. Moeleong, L. J. dan Ying, R. K. (2006). Studi Kasus: Desain dan Metode. Jakarta: Raja Grafindo Persada.

30. Moeloeng, L. J. (2005). Metodologi Penelitian Kualitatif, Edisi Revisi. Bandung: Remaja Rosdakarya.

31. Musanef. (2001). Manajemen Kepegawaiaan di Indonesia. Jakarta: Gunung Agung.

32. Nasution, S. (2003). Metode Penelitian Naturalistik Kualitatif. Bandung: Tarsito.

33. Nawawi, H. (2011). Manajemen Sumber Daya Manusia untuk Bisnis yang Kompetitif. Yogyakarta: Gadjah Mada University Press.

34. Netisimito, A. S. (2011). Manajemen Personalia: Manajemen Sumber Daya Manusia. Jakarta: Ghalia.

35. Payaman. (2011). Manajemen dan Evaluasi Kerja. Jakarta: Layanan Penerbit FE, Universitas Indonesia.

36. Poerwadarminta, W. J. (2006). Kamus Umum Bahasa Indonesia. Jakarta: Balai Pustaka.

37. (t.thn.). PUM-6.05.011 Keputusan Kasal nomor Kep/1700/XII/2014 tanggal 3 Desember 2014 tentang Buku Petunjuk Teknis Pembinaan Perwira Korps Suplai TNI Angkatan Laut.

38. Rivai, V. dan Sagala, E. J. (2014). Manajemen Sumber Daya Manusia untuk Perusahaan: dari Teori ke Praktik, edisi Ketiga. Jakarta: Raja Grafindo Persada.

39. Rivai, Veithal dan Sagala, E. J. (2009). Manajemen Sumber Daya Manusia untuk Perusahaan. Jakarta: Raja Grafindo Persada.

40. Rutman, L. (1984). Evaluation Research Methodology. New Delhi: Sage Publication India, PVT. LTD.

41. Sanders, J. R., dkk. (1994). The Program Evaluation Standards, 2nd Edition. California: Sage Publication Inc.

42. Schuler, R. dan Jackson, S. E. (2008). Manajemen Sumber Daya Manusia (Menghadapi Abad ke-21) Terjemahan Susanto. Jakarta: Gelora Aksara Pratama.

43. Shaunghnessy, J. J., dan Zeichmeister, J. S. (2012). Research Methods in Psychology. New York: McGrawHill.

44. Simamora, H. (2011). Manajemen Sumber Daya Manusia. Yogyakarta: STIE TKPN. 
45. Stake, R. E. (2003). The Countenance of Education Evaluation. Paper, Center for Instructional Research and Curriculum Evaluation, University of Illinois.

46. Steward, G. L. dan Brown, K. G. (2011). Human Resources Management: Linking Strategy to Practice, 2nd Edution. US: John Wiley \& Sons.

47. Stufflebeam, D. L. (2000). Evaluation Models, Viewpoints on Educational and Human Service Evaluation Second Edition. New York, Boston: Kluwer Academic Publishers.

48. Sudjana. (2006). Pengantar Evaluasi Pendidikan. Bandung: Raja Grafindo Persada.

49. Sudjana, D. (2006). Evaluasi Program Pendidikan Luar Sekolah. Bandung: PT. Rordakarya.

50. Sugiyono. (2014). Metode Penelitain Kuantitatif, Kualititatif dan RnD. Bandung: Alfabeta.

51. Sutikno, M. (2009). Evaluasi Program Pendidikan. Jakarta: PPs UNJ.

52. Syaodih, N. S. (2009). Metode Penelitian Pendidikan. Bandung: Remaja Rosdakarya.

53. Tanzeh, A. (2009). Pengantar Metode Penelitian. Yogyakarta: Teras.

54. Tayeb, M. H. (2005). Human Resource Management: A Multinational Company Perspective. UK: Oxford University.

55. Tayibnafis, F. Y. (2008). Evaluasi Program dan Instrumen Evaluasi: untuk Program Pendidikan dan Penelitian. Jakarta: Rineka Cipta.

56. Tayibnapis, F. Y. (2000). Evaluasi Program. Jakarta: Rineka Cipta.

57. Ted, W. dan Richard D. (2006). Pembelajaran Efektif. Terjemahan: Mustopo. Jakarta: Grasindo.

58. Thoha, M. (2003). Kepemimpinan dalam Manajemen. Jakarta: Raja Grafindo Persada.

59. Thoha, M. (2003). Pembinaan Organisasi Proses Diagnosa dan Interval. Jakarta: Raja Grafindo Persada.

60. Thoha, M. (2014). Pembinaan Organisasi. Jakarta: Raja Grafindo Persada.

61. Wahyudi, B. (2002). Manajemen Sumber Daya Manusia. Bandung: Penerbit Sulita.

62. Wibowo. (2012). Manajemen Kinerja. Jakarta: Raja Grafindo Persada.

63. Widjaja, A. W. (2006). Administrasi Kepegawaian. Jakarta: Rajawali.

64. Williams, D. D. (1988). When is Naturalistic Evaluation Appropriate? New Direction for Program Evaluation. Education Article No.30, 85-101.

65. Zainal, V. R., dkk. (2014). Manajemen Sumber Daya Manusia untuk Perusahaan: dari Teori ke Praktik, edisi Ketiga. Jakarta: Raja Grafindo Persada.

66. Zhang, G. (2011). Using the Context, Input, Process, and Product Evaluation Model (CIPP) as a Comprehensive Framework to Guide the Planning, Implementation, adn Assesment of Service-learning Program. Journal of High Education Outreach and Engagement Vol.15 No.4. 